\title{
31. THE STRONTIUM ISOTOPIC COMPOSITION OF PORE WATERS FROM LEG 133: NORTHEAST AUSTRALIAN MARGIN ${ }^{1}$
}

\author{
H. Elderfield, ${ }^{2}$ P.K. Swart, ${ }^{3}$ J.A. McKenzie, ${ }^{4}$ and A. Williams ${ }^{2}$
}

\begin{abstract}
Data are reported for strontium isotopic compositions of approximately 100 samples of pore waters recovered from the sediments of Ocean Drilling Program (ODP) Sites $812,813,814,815,817,818,823$, and 824 . Two types of pattern were found:

1. Sites 812 through 814 and 824 reflect a zoned system with the uppermost pore waters under diffusive control and with $\mathrm{Sr}$ concentrations and isotopic compositions controlled principally by dissolution of aragonite and the deeper pore waters affected by fluid flow with both $\mathrm{Sr}$ concentrations and ${ }^{87} \mathrm{Sr} /{ }^{86} \mathrm{Sr}$ ratios close to modern seawater values despite the Miocene age of the host sediment. It is possible that the fluid flow at depth is associated with a hardground between Pliocene/Pleistocene and Miocene/Pliocene sediments.

2. Pore waters from Sites $815,817,818$, and 823 show increasing salinities/chloride with depth, which may reflect the presence of evaporites beneath the drilled sections. At Site 823 , where porewater $\mathrm{Sr}$ concentrations reach nearly $3 \mathrm{mM}$, upward transport of $\mathrm{Sr}$ may be recognized from porewater ${ }^{87} \mathrm{Sr} /{ }^{86} \mathrm{Sr}$ ratios.
\end{abstract}

\section{INTRODUCTION}

Leg 133 of the Ocean Drilling Program provided a unique opportunity to study the evolution of the carbonate platforms of northeastern Australia (Fig. 1). Current knowledge about the evolution and diagenesis of carbonate platforms previously has come principally from work in the Caribbean (e.g., Mullins et al., 1984; Eberli and Ginsburg, 1989). One objective of the leg was to evaluate the diagenetic history and processes that operate on contrasting mixed carbonate/siliciclastic and pure carbonate margins in an environment considered to be undersaturated with respect to both aragonite and high-magnesium calcite at relatively shallow water depths.

A topic of particular importance was whether evidence for fluid flow through the carbonate platforms could be found. Mullins et al. (1984) and Simms (1984) proposed that the diagenesis of carbonate platforms can be controlled by fluid flow, resulting in the conversion of metastable minerals, such as high-magnesium calcite and aragonite, to low-magnesium calcite and the formation of dolomite. However, evidence for large-scale fluid flow was not found at previous ODP sites adjacent to carbonate platforms, such as in the Bahamas (Swart and Guzikowski, 1988) and the Maldives (Swart and Burns, 1990). Another topic of interest was that previous work on hemipelagic sediments drilled by ODP has shown evidence for the presence of evaporites at depth (Elderfield et al., 1991; Kastner et al., 1990) that can influence diagenetic processes.

Here, the results of measurements made of the ${ }^{87} \mathrm{Sr} /{ }^{86} \mathrm{Sr}$ ratios of Leg 133 pore waters are presented and a preliminary account is given of the processes defining the $\mathrm{Sr}$ isotope-depth profiles. Data for $\mathrm{Sr}$ isotopic compositions of pore waters provide important information about diagenetic processes (Elderfield and Gieskes, 1982). The $\mathrm{Sr}$ isotopic composition of seawater is known to have changed with time (Burke et al., 1982), with the result that Sr incorporated into primary carbonate minerals records the $\mathrm{Sr}$ isotopic composition of seawater

'McKenzie, J.A., Davies, P.J., Palmer-Julson, A., et al., 1993.Proc. ODP, Sci. Results, 133: College Station, TX (Ocean Drilling Program).

${ }^{2}$ Department of Earth Sciences, University of Cambridge. Downing Street, Cambridge CB2 3EQ, U.K.

${ }^{3}$ Division of Marine Geology and Geophysics, Rosenstiel School of Marine and Atmospheric Science, University of Miami, 4600 Rickenbacker Causeway, Miami, FL 33149-1098, U.S.A.

${ }^{4}$ Geologisches Institut, Eidgenossische Technische Hochschule, Sonneggstrasse 5, CH-8092, Zurich, Switzerland. of the age of deposition. In general, seawater ${ }^{87} \mathrm{Sr} /{ }^{86} \mathrm{Sr}$ ratios increased through the Cenozoic, although these rates of increase have varied significantly; thus, the seawater $\mathrm{Sr}$ isotope curve provides a template against which other data may be compared, either for an empirical assessment of age or to identify processes that have modified the expected changes in ${ }^{87} \mathrm{Sr} /{ }^{86} \mathrm{Sr}$ ratios with depth or time.

Changes in the $\mathrm{Sr}$ isotopic composition of seawater with time also are reflected in the depth profiles of pore waters, which tend to show decreasing ${ }^{87} \mathrm{Sr} /{ }^{86} \mathrm{Sr}$ ratios with depth, although the primary signal of buried seawater is modified by Sr diagenesis and transport. Recrystallization of primary carbonates results in the release of $\mathrm{Sr}$ to pore waters, modifying the shapes of the pore-water profiles (Baker et al., 1982; Richter and DePaolo, 1987). In general, in carbonate-rich sites, pore waters are characterized by Sr profiles that increase steeply with depth to concentrations up to an order of magnitude higher than seawater values (Elderfield and Gieskes, 1982), and ${ }^{87} \mathrm{Sr} /{ }^{86} \mathrm{Sr}$ ratios depart from values predicted from the age of the sediment by transport of $\mathrm{Sr}$ away from the zone of maximum recrystallization. Influx of $\mathrm{Sr}$ from nonseawater sources, such as volcanic ash or clay minerals, also changes ${ }^{87} \mathrm{Sr} /{ }^{86} \mathrm{Sr}$ ratios as does transport of $\mathrm{Sr}$ by advection from sources external to the sediments, such as from underlying oceanic crust (Baker et al., 1991), with the result that depth profiles of $\mathrm{Sr}$ isotope ratios provide a valuable method for identifying processes that modify sediments, especially when considered in conjunction with other pore-water and sediment chemistry and mineralogy.

\section{METHODS}

Pore waters were extracted using a stainless-steel Manhein-type squeezer (Sayles et al., 1973) at room temperature and filtered through $0.45 \mu \mathrm{m}$ Gelman acrodisk disposable filters prior to shipboard analysis and storage of samples for shore-based analysis. The details of the shipboard procedures are summarized in the introduction and the results of the shipboard analytical program are listed in the Initial Reports, Volume 133 (Davies, McKenzie, Palmer-Julson, et al., 1991).

Pore-water samples for $\mathrm{Sr}$ isotopic analysis were heat-sealed in plastic tubing after extraction and transported to Cambridge for analysis. Strontium was separated from $100 \mu \mathrm{L}$ aliquots by conventional cation exchange chromatography and ${ }^{87} \mathrm{Sr} /{ }^{86} \mathrm{Sr}$ ratios determined using a VG Isomass 54E mass spectrometer equipped with a single collector (Elderfield et al., 1991). Some samples were analyzed using a VG Sector 54 instrument with seven collectors using a multidynamic peak 


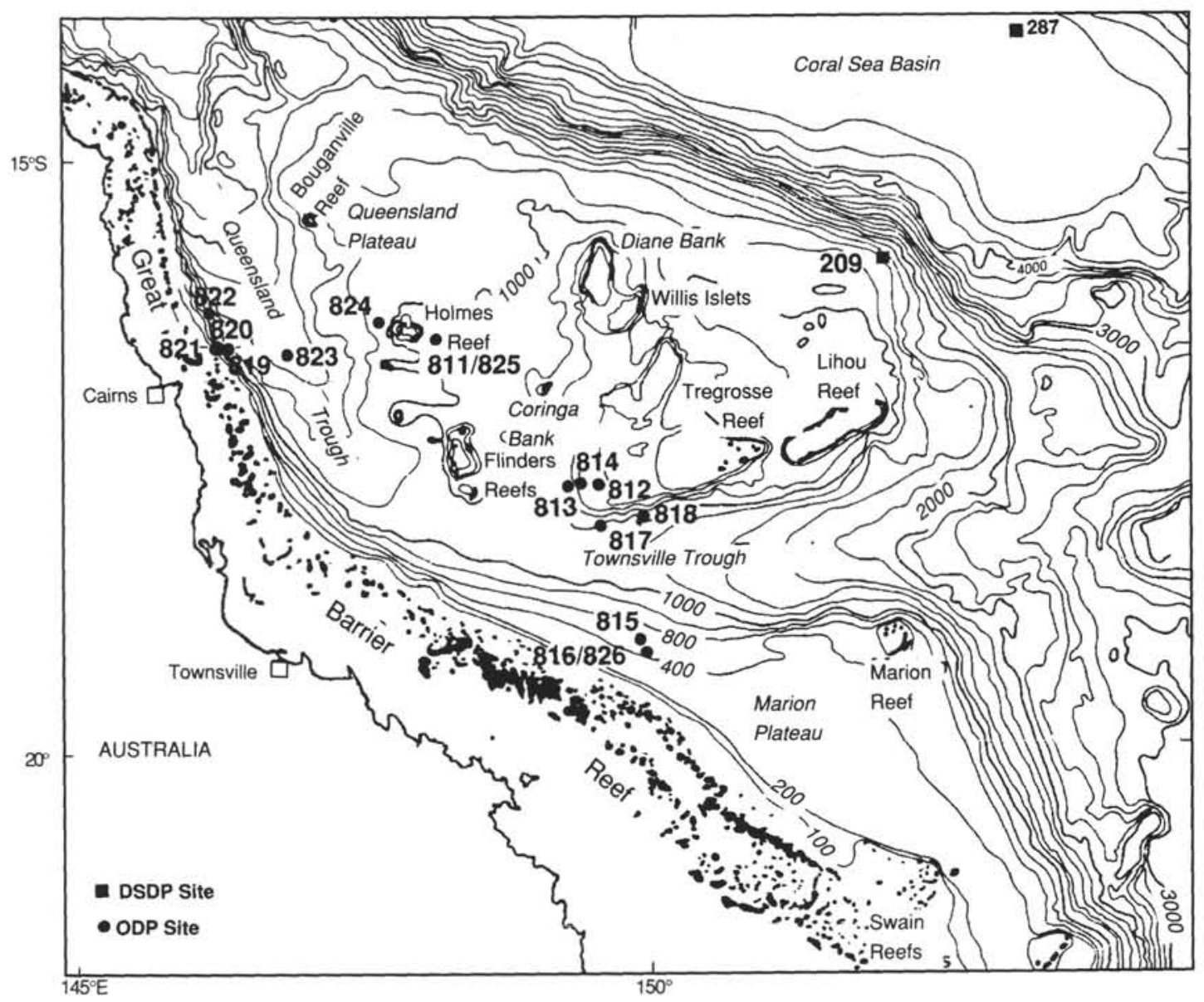

Figure 1. Map of study area showing positions of Leg 133 sites.

switching program. Results obtained for $\mathrm{NBS} 987 \mathrm{SrCO}_{3}$ standard during the course of the work gave ${ }^{87} \mathrm{Sr}{ }^{86} \mathrm{Sr}=0.71023$, and samples of an in-house seawater standard gave ${ }^{87} \mathrm{Sr} /{ }^{86} \mathrm{Sr}=0.70917$.

\section{RESULTS}

$\mathrm{Sr}$ isotopic values were determined for a total of 97 pore-water samples from Sites $812,813,814,815,817,818,823$, and 824, the locations of which are shown in Figure 1 and summarized in Table 1. Results are listed in Table 2, alongside shipboard data about $\mathrm{Sr}$ concentrations. Depth profiles of ${ }^{87} \mathrm{Sr} /{ }^{86} \mathrm{Sr}$ ratios and $\mathrm{Sr}$ concentrations in the pore waters are shown in Figures $2 \mathrm{~A}$ through $2 \mathrm{H}$.

\section{Site 812}

Site 812 is located on the southern margin of the Queensland Plateau between the Flinders and Tregrosse reefs. Together with Sites 813 and 814 , it represents a transect across a platform-slope transition, with Site 812 being the lagoonal-bank end-member. The oldest sediment recovered was middle Miocene (189.9 mbsf) and the age of the oldest sediment from which pore water was obtained was late middle to early late Miocene (121.4 mbsf).

Strontium concentrations in pore waters (Fig. 2A) increase with increasing depth from above seawater values $(\sim 96 \mu \mathrm{M})$ to nearly $120 \mu \mathrm{M}$ at $22 \mathrm{mbsf}$, below which concentrations decrease to constant values $(103 \mu \mathrm{M})$, somewhat higher than the modern seawater concentration. The increase in pore-water $\mathrm{Sr}$ from the top of the hole to $22 \mathrm{mbsf}$ is associated with a decrease in the aragonite content of the sediment from $\sim 50 \%$ at the top of the hole and its disappearance just below where pore-water $\mathrm{Sr}$ is at its maximum (Fig. 3A).

The decrease in pore-water $\mathrm{Sr}$ below $\sim 25 \mathrm{mbsf}$ is atypical of pore waters of carbonate-rich sediments drilled by DSDP/ODP, which normally show increases to constant $\mathrm{Sr}$ concentrations at depth (see Elderfield and Gieskes, 1982). The depth of the pore-water Sr maximum corresponds approximately to the Unit I/Unit II boundary (Davies, McKenzie, Palmer-Julson, et al., 1991). In Unit I of mainly Pleistocene age, ${ }^{87} \mathrm{Sr} /{ }^{86} \mathrm{Sr}$ ratios decrease with depth, similar to the changing ${ }^{87} \mathrm{Sr} /{ }^{86} \mathrm{Sr}$ ratio of seawater for this age range. However, below this boundary, ${ }^{87} \mathrm{Sr} /{ }^{86} \mathrm{Sr}$ ratios increase to values similar to those for modern seawater. ${ }^{87} \mathrm{Sr} /{ }^{86} \mathrm{Sr}$ ratios corresponding to the ages of the sediments (late Miocene to Pliocene) would be expected to decrease with depth to $\sim 0.7089$ (Fig. 4). As with the $\mathrm{Sr}$ data, this feature is unusual for carbonate-rich sediments.

Table 1. Leg 133 sites at which ${ }^{87} \mathrm{Sr} /{ }^{86} \mathrm{Sr}$ porewater analyses took place.

\begin{tabular}{cccc}
\hline Site & Latitude & Longitude & Water depth $(\mathrm{m})$ \\
\hline 812 & $17^{\circ} 48.84^{\prime} \mathrm{S}$ & $149^{\circ} 36.31^{\prime} \mathrm{E}$ & 937 \\
813 & $17^{\circ} 49.95^{\prime} \mathrm{S}$ & $149^{\circ} 29.67^{\prime} \mathrm{E}$ & 539 \\
814 & $17^{\circ} 49.99^{\prime} \mathrm{S}$ & $149^{\circ} 30.83^{\prime} \mathrm{E}$ & 520 \\
815 & $19^{\circ} 09.03^{\prime} \mathrm{S}$ & $149^{\circ} 99.51^{\prime} \mathrm{E}$ & 466 \\
817 & $18^{\circ} 09.49^{\prime} \mathrm{S}$ & $149^{\circ} \circ 5.50^{\prime} \mathrm{E}$ & 1016 \\
818 & $18^{\circ} 03.77^{\prime} \mathrm{S}$ & $150^{\circ} 02.52^{\prime} \mathrm{E}$ & 748 \\
823 & $16^{\circ} 36.98^{\prime} \mathrm{S}$ & $146^{\circ} 47.05^{\prime} \mathrm{E}$ & 1638 \\
824 & $16^{\circ} 26.70^{\prime} \mathrm{S}$ & $147^{\circ} 45.73^{\prime} \mathrm{E}$ & 1000 \\
\hline
\end{tabular}


A
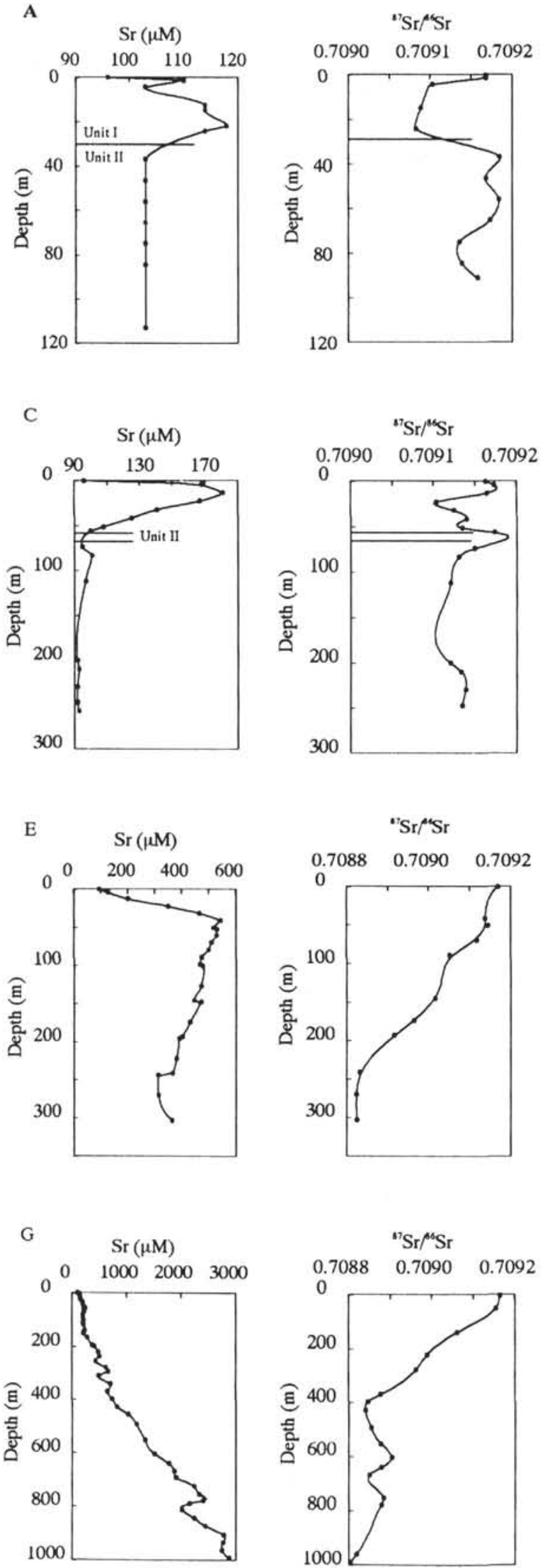

B
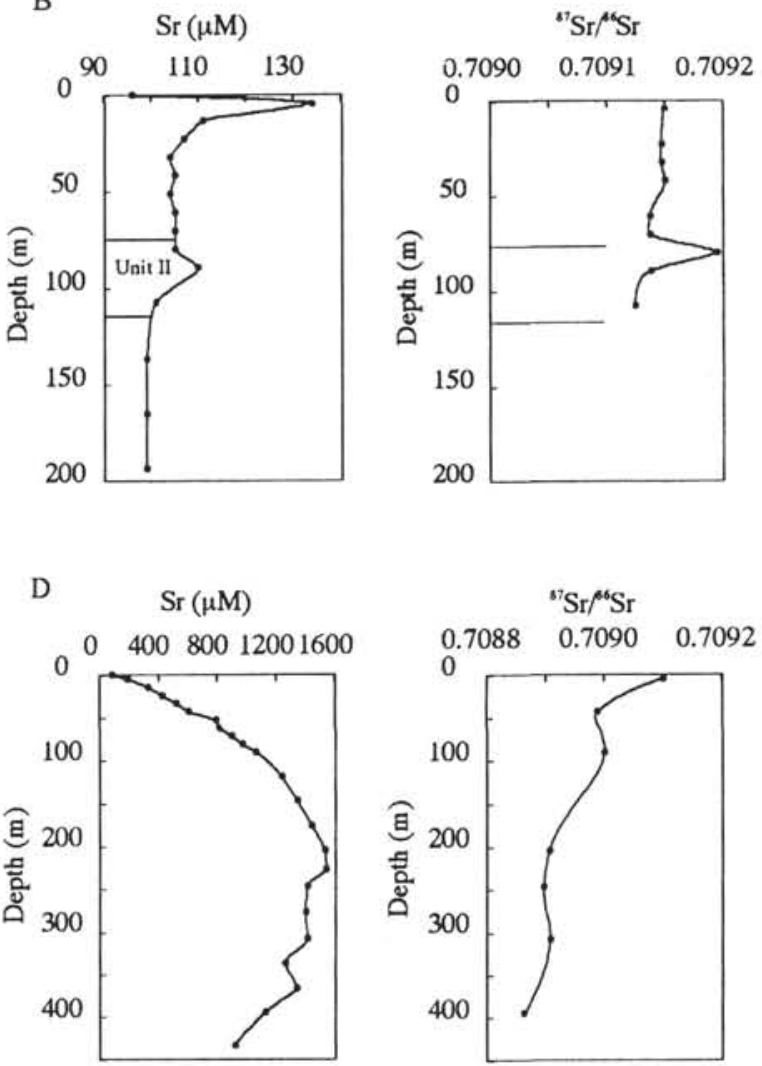

F
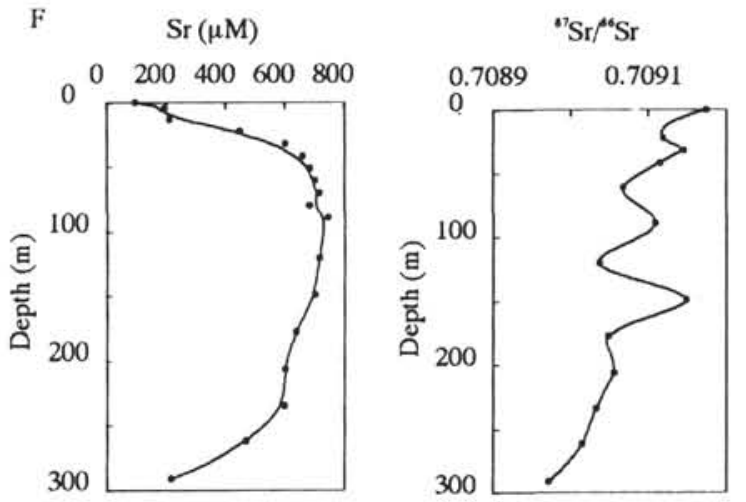

H

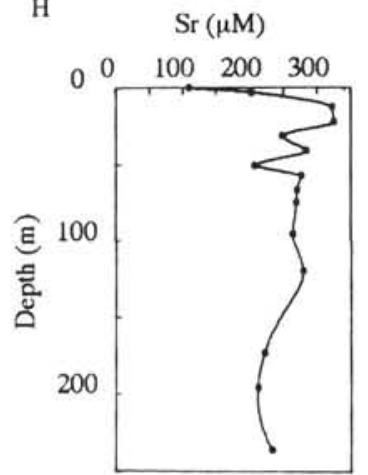

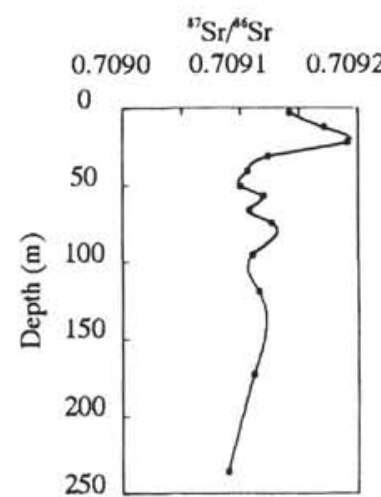

Figure 2. Depth profiles of Sr concentrations and ${ }^{87} \mathrm{Sr} /{ }^{86} \mathrm{Sr}$ ratios in Leg 133 pore waters. A. Site 812. B. Site 813. C. Site 814 . D. Site 815 . E. Site 817. F. Site 818 . G. Site 823 . H. Site 824. 
Table $2 .{ }^{87} \mathrm{Sr}{ }^{86} \mathrm{Sr}$ ratios and $\mathrm{Sr}$ concentrations of $\mathrm{Leg} 133$ pore waters.

\begin{tabular}{|c|c|c|c|c|c|c|c|c|}
\hline & Core, section, interval $(\mathrm{cm})$ & $\begin{array}{l}\text { Depth } \\
\text { (mbsf) }\end{array}$ & $\begin{array}{c}\mathrm{Sr} \\
(\mu \mathrm{M})\end{array}$ & ${ }^{87} \mathrm{Sr} /{ }^{86} \mathrm{Sr}\left( \pm 10^{6 *} 2 \sigma\right)$ & Core, section, interval $(\mathrm{cm})$ & $\begin{array}{l}\text { Depth } \\
\text { (mbsf) }\end{array}$ & $\begin{array}{c}\mathrm{Sr} \\
(\mu \mathrm{M})\end{array}$ & ${ }^{87} \mathrm{Sr} /{ }^{86} \mathrm{Sr}\left( \pm 10^{6 *} 2 \sigma\right)$ \\
\hline \multirow[t]{16}{*}{$\begin{array}{r}\text { Site } 812 \\
133-\end{array}$} & Seawater & 0 & 96 & $0.709168(32)$ & $\begin{array}{l}7 \mathrm{H}-1,0-7 \\
7 \mathrm{H}-5,145-150\end{array}$ & $\begin{array}{l}53.2 \\
60.65\end{array}$ & $\begin{array}{l}531 \\
530\end{array}$ & $\overline{-}$ \\
\hline & $812 \mathrm{~A}-1 \mathrm{H}-1,145-150$ & 1.45 & 110 & $0.709168(32)$ & $8 \mathrm{H}-5,145-150$ & 70.25 & 512 & $0.709118(36)$ \\
\hline & $812 \mathrm{C}-1 \mathrm{H}-3,145-150$ & 4.45 & 103 & $0.709103(62)$ & $9 \mathrm{H}-5,145-150$ & 79.65 & 500 & 0.1001000 \\
\hline & $812 \mathrm{~A}-2 \mathrm{H}-5,145-150$ & 12.35 & 114 & - & $10 \mathrm{H}-5,145-150$ & 89.15 & 475 & $0.709052(24)$ \\
\hline & $812 \mathrm{C}-2 \mathrm{H}-5,145-150$ & 14.8 & 114 & $0.709089(78)$ & $11 \mathrm{H}-5,145-150$ & 98.65 & 468 & - \\
\hline & $812 \mathrm{~A}-3 \mathrm{H}-5,145-150$ & 21.85 & 118 & - & $12 \mathrm{H}-1,0-7$ & 100.7 & 478 & - \\
\hline & $812 \mathrm{C}-3 \mathrm{H}-5,145-150$ & 24.37 & 114 & $0.709083(38)$ & $14 \mathrm{H}-5,145-150$ & 127.15 & 473 & - \\
\hline & $812 \mathrm{C}-5 \mathrm{H}-5,145-150$ & 36.97 & 103 & $0.709185(28)$ & $16 \mathrm{H}-5,145-150$ & 146.15 & 446 & $0.709016(20)$ \\
\hline & $812 \mathrm{C}-6 \mathrm{H}-5,145-150$ & 46.47 & 103 & $0.709168(30)$ & $17 \mathrm{H}-1,0-7$ & 148.2 & 472 & - \\
\hline & $812 \mathrm{C}-7 \mathrm{H}-5,145-150$ & 55.97 & 103 & $0.709184(28)$ & $19 \mathrm{H}-5,142-150$ & 174.62 & 432 & $0.708965(20)$ \\
\hline & $812 \mathrm{C}-8 \mathrm{H}-5,145-150$ & 65.47 & 103 & $0.709173(52)$ & $21 \mathrm{H}-5,140-150$ & 193.6 & 403 & $0.708916(20)$ \\
\hline & $812 \mathrm{C}-9 \mathrm{H}-5,145-150$ & 74.97 & 103 & $0.709136(78)$ & $22 \mathrm{H}-1,0-7$ & 195.7 & 393 & - \\
\hline & $812 \mathrm{C}-10 \mathrm{H}-5,145-150$ & 84.47 & 103 & $0.709139(38)$ & $24 \mathrm{X}-5,140-150$ & 222.1 & 382 & - \\
\hline & $812 \mathrm{~A}-12 \mathrm{X}-5,145-150$ & 91.05 & 112 & $0.709158(60)$ & $26 \mathrm{X}-5,140-150$ & 241.4 & 367 & $0.708833(18)$ \\
\hline & $812 \mathrm{C}-13 \mathrm{H}-5,145-150$ & 112.97 & 103 & - & $27 \mathrm{X}-1.0-7$ & 243.7 & 314 & - \\
\hline & & & & & $29 \times-5,140-150$ & 270.4 & 315 & $0.708824(20)$ \\
\hline \multirow[t]{16}{*}{$\begin{array}{l}\text { Site } 813 \\
\quad 133-813 \mathrm{~A}\end{array}$} & $\begin{array}{l}\text { Seawater } \\
\text { A- }\end{array}$ & 0 & 96 & $0.709160(20)$ & $5 R-3,140-150$ & 303.4 & 365 & $0.708826(30)$ \\
\hline & IH-3, $145-150$ & 4.45 & 134 & $0.709149(42)$ & Seawater & 0 & 97 & $0.709173(22)$ \\
\hline & $2 \mathrm{H}-5,145-150$ & 13.17 & 111 & $\begin{array}{c}0.103149(42) \\
-\end{array}$ & $133-818 \mathrm{~A}$ - & & & 0.108 \\
\hline & $3 \mathrm{H}-5,145-150$ & 22.67 & 107 & $0.709147(24)$ & $1 \mathrm{H}-4,145-150$ & 4.49 & 196 & - \\
\hline & $4 \mathrm{H}-5,145-150$ & 32.17 & 104 & $0.709147(20)$ & $2 \mathrm{H}-5,145-150$ & 12.99 & 211 & - \\
\hline & $5 \mathrm{H}-5,145-150$ & 41.67 & 105 & $0.70915(24)$ & $3 \mathrm{H}-5,145-150$ & 22.46 & 449 & $0.709118(40)$ \\
\hline & $6 \mathrm{H}-5,145-150$ & 51.17 & 104 & - & $4 \mathrm{H}-5,145-150$ & 31.99 & 603 & $0.709144(20)$ \\
\hline & $7 \mathrm{H}-5,145-150$ & 60.67 & 105 & $0.709137(32)$ & $5 \mathrm{H}-5,145-150$ & 41.49 & 662 & $0.709114(30)$ \\
\hline & $8 \mathrm{H}-5,145-150$ & 70.17 & 105 & $0.709137(18)$ & $6 \mathrm{H}-5,145-150$ & 50.99 & 685 & - \\
\hline & $9 \mathrm{H}-5,145-150$ & 79.67 & 105 & $0.709194(38)$ & $7 \mathrm{H}-5,140-150$ & 60.49 & 704 & $0.709067(26)$ \\
\hline & $10 \mathrm{H}-5,145-150$ & 89.17 & 110 & $0.709138(20)$ & $8 \mathrm{H}-5,145-150$ & 69.99 & 716 & - \\
\hline & $12 \mathrm{H}-5,145-150$ & 107.47 & 101 & $0.709124(30)$ & $9 \mathrm{H}-5,140-150$ & 79.49 & 685 & - \\
\hline & $15 \mathrm{H}-5,145-150$ & 136.67 & 99 & - & $10 \mathrm{H}-5,140-150$ & 88.99 & 746 & $0.709108(28)$ \\
\hline & $18 \mathrm{H}-5,145-150$ & 165.17 & 99 & - & $13 \mathrm{H}-5,140-150$ & 120.53 & 716 & $0.709036(24)$ \\
\hline & $21 \mathrm{H}-5,145-150$ & 193.67 & 99 & - & $16 \mathrm{H}-5,140-150$ & 148.91 & 704 & $0.709148(64)$ \\
\hline & & & & & $19 \mathrm{H}-5,140-150$ & 177.5 & 638 & $0.709048(20)$ \\
\hline \multirow{18}{*}{$\begin{array}{l}\text { Site } 814 \\
\quad 133-814 A\end{array}$} & Seawater & 0 & 96 & $0.709163(20)$ & $22 \mathrm{H}-5,140-150$ & 206 & 601 & $0.709055(18)$ \\
\hline & & & & & $25 \mathrm{H}-5,140-150$ & 234.51 & 599 & $0.709032(36)$ \\
\hline & $1 \mathrm{H}-3,145-150$ & 4.45 & 168 & $0.709173(26)$ & $28 \mathrm{H}-5,140-150$ & 262 & 470 & $0.709014(18)$ \\
\hline & $2 \mathrm{H}-5,145-150$ & 13.37 & 181 & $0.709165(20)$ & $31 \mathrm{H}-5,140-150$ & 291 & 217 & $0.708971(21)$ \\
\hline & $3 \mathrm{H}-5,145-150$ & 22.87 & 167 & $0.709104(26)$ & & & & \\
\hline & $4 \mathrm{H}-5,145-150$ & 32.37 & 141 & $0.709125(20)$ & Seawater & 0 & 105 & $0.70916(20)$ \\
\hline & $5 \mathrm{H}-5,145-150$ & 41.87 & 125 & $0.70914(24)$ & $133-823 \mathrm{~A}-$ & & & \\
\hline & $6 \mathrm{H}-5,145-150$ & 51.37 & 108 & $0.709135(20)$ & $1 \mathrm{H}-3,145-150$ & 4.45 & 133 & $0.709165(23)$ \\
\hline & $7 \mathrm{H}-2,145-150$ & 56.3 & 100 & $0.709174(6)$ & $2 \mathrm{H}-5,145-150$ & 13.25 & 148 & - \\
\hline & $9 \mathrm{H}-5,145-150$ & 73.97 & 95 & $0.70915(24)$ & $3 \mathrm{H}-5,145-150$ & 22.75 & 157 & - \\
\hline & $10 \mathrm{H}-5,145-150$ & 83.47 & 101 & 0.709131 (18) & $4 \mathrm{H}-5,145-150$ & 32.25 & 190 & - \\
\hline & $13 \mathrm{H}-5,145-150$ & 111.97 & 97 & $0.709121(18)$ & $5 \mathrm{H}-5,145-150$ & 41.75 & 202 & - \\
\hline & $23 \mathrm{H}-1,145-150$ & 200.1 & 92 & $0.709121(20)$ & $6 \mathrm{H}-5,145-150$ & 51.25 & 218 & $0.709155(18)$ \\
\hline & $24 \mathrm{H}-2,145-150$ & 209.8 & 93 & $0.709134(26)$ & $7 \mathrm{H}-1,0-7$ & 55.8 & 241 & - \\
\hline & $26 \mathrm{H}-3,145-150$ & 230.2 & 92 & $0.709139(20)$ & $7 \mathrm{H}-5,145-150$ & 60.75 & 220 & - \\
\hline & $28 \mathrm{H}-2,145-150$ & 247.6 & 92 & $0.709135(20)$ & $8 \mathrm{H}-5,145-150$ & 70.25 & 221 & - \\
\hline & $29 \mathrm{H}-2,145-150$ & 257.2 & 93 & - & $9 \mathrm{H}-5,145-150$ & 79.75 & 201 & - \\
\hline & & & & & $10 \mathrm{H}-5,145-150$ & 89.25 & 196 & - \\
\hline Site 815 & Seawater & 0 & 86 & $0.709160(20)$ & $12 \mathrm{H}-1,0-7$ & 103.3 & 212 & - \\
\hline $133-815 A$ & & & & & $12 \mathrm{H}-5,145-150$ & 110.7 & 197 & - \\
\hline & $1 \mathrm{H}-3,145-150$ & 4.45 & 193 & $0.709102(22)$ & $13 \mathrm{H}-5,145-150$ & 117.75 & 216 & - \\
\hline & $2 \mathrm{H}-5,145-150$ & 14.25 & 335 & $0.7030(22)$ & $15 \mathrm{X}-5,140-150$ & 139.5 & 234 & $0.709062(24)$ \\
\hline & $3 \mathrm{H}-5,145-150$ & 23.8 & 431 & _- & $17 X-1,0-7$ & 151.4 & 211 & - \\
\hline & $4 \mathrm{H}-5,145-150$ & 33.25 & 526 & - & $18 \times-3,0-7$ & 165.5 & 282 & - \\
\hline & $5 \mathrm{H}-5,145-150$ & 42.75 & 610 & $0.708989(21)$ & $21 X-3,140-150$ & 194.6 & 374 & - \\
\hline & $6 \mathrm{H}-5,145-150$ & 52.25 & 798 & - & $22 X-1,0-7$ & 199.8 & 409 & - \\
\hline & $7 \mathrm{H}-5,145-150$ & 61.75 & 817 & - & $24 \mathrm{X}-2,140-150$ & 221.6 & 477 & $0.70899(26)$ \\
\hline & $8 \mathrm{H}-5,145-150$ & 71.25 & 897 & - & $26 \times-1,0-7$ & 237.7 & 505 & - \\
\hline & $9 \mathrm{H}-5,145-150$ & 80.75 & 973 & - & $27 \mathrm{X}-6,140-150$ & 256.2 & 432 & - \\
\hline & $10 \mathrm{H}-5,145-150$ & 90.2 & 1063 & $0.709001(38)$ & $30 \times-2,140-150$ & 279.2 & 619 & $0.708962(18)$ \\
\hline & $13 \mathrm{H}-5,145-150$ & 118.7 & 1239 & $0.70001(50)$ & $32 \mathrm{X}-1,0-7$ & 295.6 & 662 & - \\
\hline & $16 \mathrm{H}-5,145-150$ & 147.2 & 1347 & - & $33 \mathrm{X}-4,140-150$ & 311.2 & 494.5 & - \\
\hline & $19 \mathrm{H}-5,145-150$ & 175.7 & 1445 & - & $36 \times-5,140-150$ & 341.6 & 703 & - \\
\hline & $22 \mathrm{H}-3,145-150$ & 204.2 & 1534 & $0.708907(21)$ & $39 \mathrm{X}-5,140-150$ & 370.4 & 654 & $0.708878(26)$ \\
\hline & $26 \mathrm{X}-3,145-150$ & 226.9 & 1541 & - & $42 X-4,140-150$ & 397.9 & 742 & $0.708846(40)$ \\
\hline & $28 \mathrm{X}-3,145-150$ & 246.2 & 1412 & $0.708897(18)$ & $45 X-5,140-150$ & 428.3 & 825 & $0.70884(30)$ \\
\hline & $31 X-4,145-150$ & 276.7 & 1400 & $0.70003(10)$ & $48 \times-4,140-150$ & 455.8 & 1029 & - \\
\hline & $34 X-5,145-150$ & 307.3 & 1414 & $0.708908(21)$ & $52 X-4,140-150$ & 493.7 & 1185 & $0.708855(30)$ \\
\hline & $37 X-5,145-150$ & 336.4 & 1261 & 0 & $58 \mathrm{X}-5,140-150$ & 552.8 & 1338 & $0.708878(26)$ \\
\hline & $40 X-5,145-150$ & 365.5 & 1342 & - & $64 \mathrm{X}-1,135-150$ & 604.55 & 1515 & $0.708904(24)$ \\
\hline & $43 \mathrm{X}-5,145-150$ & 394.5 & 1124 & $0.708864(21)$ & $67 X-5,135-150$ & 639.55 & 1780 & $0.708879(28)$ \\
\hline & $47 X-5,145-150$ & 432.7 & 920 & - & $70 \mathrm{X}-5,110-125$ & 667.75 & 1879 & $0.70885(22)$ \\
\hline & & & & & $73 \times-2,135-150$ & 692.45 & 1913 & - \\
\hline Site 817 & Seawater & 0 & 94 & $0.709170(24)$ & $76 \times-4,135-150$ & 724.45 & 2248 & - \\
\hline $133-817 A$ & & & & & $79 \times-4,135-150$ & 753.45 & 2335 & $0.708884(34)$ \\
\hline & $1 \mathrm{H}-3,145-150$ & 4.45 & 127 & - & $82 X-1,135-150$ & 778.05 & 2410 & $0.708879(22)$ \\
\hline & $2 \mathrm{H}-5,145-150$ & 13.15 & 201 & - & $1 \mathrm{R}-3,130-150$ & 788.3 & 2162 & - \\
\hline & $3 \mathrm{H}-5,145-150$ & 22.65 & 350 & - & $4 \mathrm{R}-1,130-150$ & 813.9 & 2023 & - \\
\hline & $4 \mathrm{H}-5,145-150$ & 32.15 & 466 & - & $7 \mathrm{R}-2,130-150$ & 844.5 & 2248 & - \\
\hline & $5 \mathrm{H}-5,145-150$ & 41.65 & 544 & $0.709138(24)$ & $10 \mathrm{R}-1,125-150$ & 872.05 & 2444 & - \\
\hline & $6 \mathrm{H}-5,145-150$ & 51.15 & 517 & $0.709145(26)$ & $13 \mathrm{R}-4,130-150$ & 905.6 & 2785 & - \\
\hline
\end{tabular}




\begin{tabular}{rlrrr}
\hline & Core, section, interval $(\mathrm{cm})$ & $\begin{array}{c}\text { Depth } \\
(\mathrm{mbs})\end{array}$ & $\begin{array}{c}\mathrm{Sr} \\
(\mu \mathrm{M})\end{array}$ & ${ }^{87} \mathrm{Sr} /{ }^{86} \mathrm{Sr}\left( \pm 10^{6 *} 2 \sigma\right)$ \\
\hline & $16 \mathrm{R}-4,130-150$ & 934.6 & 2774 & - \\
& 19R-3, 130-150 & 961.6 & 2750 & $0.708819(18)$ \\
& 22R-3, 130-150 & 990.5 & 2877 & $0.708804(18)$ \\
Site 824 & Seawater & 0 & 110 & $0.709160(20)$ \\
$133-$ & & & & \\
& 824B-1H-2, 145-150 & 2.95 & 203 & $0.709142(26)$ \\
& 824B-2H-5, 145-150 & 12.45 & 323 & $0.709172(26)$ \\
& 824B-3H-5, 145-150 & 21.95 & 326 & $0.709192(26)$ \\
& 824B-4H-5, 145-150 & 31.45 & 249 & $0.709124(36)$
\end{tabular}

A

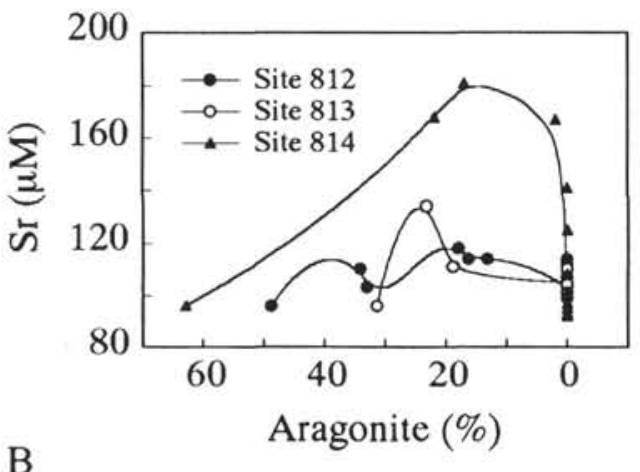

$\mathrm{B}$

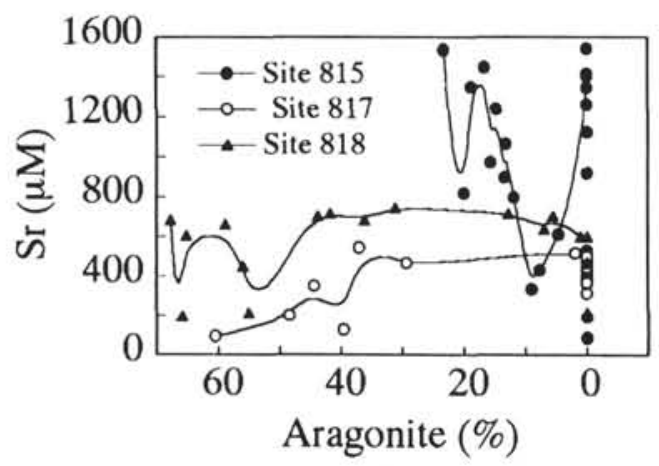

Figure 3. Plots of pore-water $\mathrm{Sr}$ concentrations vs. percentage of aragonite in sediments. A. Sites 812 through 814 . B. Sites $815,817,818$.

\section{Site 813}

Site 813 is located on the southwestern edge of the Tregrosse/Lihou/Coringa Bank complex and, with Sites 812 and 814 , forms a three-site transect across a platform-slope transition, with Site 813 representing the most distal part of an aggradational/progradational sequence. As at Site 812, the oldest sediment recovered was middle Miocene in age.

$\mathrm{Sr}$ concentrations in the pore waters (Fig. 2B) exhibit features similar to those at Site 812. Concentrations increase to in excess of $130 \mu \mathrm{M}$ at shallow depth ( $\sim 5 \mathrm{mbsf})$ and then decrease to a constant value slightly above seawater concentration $(\sim 105 \mu \mathrm{M})$ down to $\sim 107$ mbsf. Below this, they decrease further to a constant value of $\sim 100$ $\mu \mathrm{M}$. The zone of rapidly increasing pore-water $\mathrm{Sr}$ corresponds to that of aragonite dissolution and, as at Site 812, the increase in strontium is correlated with decreasing aragonite content of the sediment, such that the disappearance of aragonite occurs just below the pore-water Sr maximum (Fig. 3A).

The profile of ${ }^{87} \mathrm{Sr} /{ }^{86} \mathrm{Sr}$ ratio with depth is significantly different than that for the seawater $\mathrm{Sr}$ isotope curve (Fig. 4). As compared with the range between modern seawater and Miocene seawater values,

\begin{tabular}{|c|c|c|c|}
\hline Core, section, interval $(\mathrm{cm})$ & $\begin{array}{l}\text { Depth } \\
\text { (mbsf) }\end{array}$ & $\begin{array}{c}\mathrm{Sr} \\
(\mu \mathrm{M})\end{array}$ & ${ }^{87} \mathrm{Sr} /{ }^{86} \mathrm{Sr}\left( \pm 10^{6 *} 2 \sigma\right)$ \\
\hline $824 \mathrm{~B}-5 \mathrm{H}-5,145-150$ & 40.95 & 285 & $0.709107(34)$ \\
\hline $824 \mathrm{~B}-6 \mathrm{H}-5,145-150$ & 50.45 & 208 & $0.709100(32)$ \\
\hline $824 \mathrm{~A}-1 \mathrm{H}-5,145-150$ & 57.4 & 277 & $0.709120(22)$ \\
\hline $824 \mathrm{~A}-2 \mathrm{H}-5,145-150$ & 66.9 & 271 & $0.709108(22)$ \\
\hline $824 \mathrm{~A}-3 \mathrm{H}-4,145-150$ & 74.9 & 270 & $0.709127(44)$ \\
\hline $824 \mathrm{~A}-5 \mathrm{H}-5,145-150$ & 95.4 & 265 & $0.709111(22)$ \\
\hline $824 \mathrm{~A}-8 \mathrm{H}-2,145-150$ & 119.4 & 280 & $0.709116(18)$ \\
\hline $824 \mathrm{~A}-14 \mathrm{H}-5,145-150$ & 173.1 & 223 & $0.709112(24)$ \\
\hline $824 \mathrm{~A}-17 \mathrm{X}-2,145-150$ & 195.95 & 212 & - \\
\hline $824 \mathrm{~A}-21 \mathrm{X}-2,145-150$ & 235.6 & 234 & $0.70909(28)$ \\
\hline
\end{tabular}

${ }^{87} \mathrm{Sr} /{ }^{86} \mathrm{Sr}$ ratios remain only slightly lower than that for modern seawater throughout the hole. There is a small shift from 0.70914 to 0.70915 within the top $\sim 80 \mathrm{~m}$ and from 0.70912 to 0.70914 below $\sim 90 \mathrm{~m}$. The boundary zone corresponds approximately to where the small shift in pore-water $\mathrm{Sr}$ occurs, which is associated with the changes in lithology and physical properties at the boundaries of Unit II with Units I and III (Fig. 2B).

\section{Site 814}

Site 814 is located on the southwestern edge of the Tregrosse/Lihou/Coringa Bank complex, in front of a carbonate bank and represents the proximal transition between the lagoonal bank (Site 812) and the distal part (Site 813) of the three-site aggradational/progradational sequence. The oldest sediments recovered (300 mbsf) were middle Miocene or older.

The pore-water depth distributions of $\mathrm{Sr}$ and ${ }^{87} \mathrm{Sr} /{ }^{86} \mathrm{Sr}$ ratios (Fig. 2C) show similarities to those of the other transect sites, especially those of Site 812. Concentrations of $\mathrm{Sr}$ increase with depth and are associated with aragonite dissolution (Fig. 3A), and then decrease to a value slightly lower than that for seawater at $\sim 50 \mathrm{mbsf}$, below which they remain constant over the interval sampled. The upper $\sim 50 \mathrm{~m}$ (Unit I) is of Pleistocene to late Pliocene age, but pore-water ${ }^{87} \mathrm{Sr} /{ }^{86} \mathrm{Sr}$ ratios follow the seawater $\mathrm{Sr}$ isotope curve only for the top $23 \mathrm{~m}$ of the hole and then increase to a near-modern seawater value within Unit II, below which they decrease to near-constant values of $\sim 0.70912$ to 0.70914 over the remainder of the hole. As with Sites 812 and 813, these ratios are much higher than those for seawater of the age of the associated sediment (Fig. 4).

\section{Site 815}

Site 815 is located along the southern margin of the Townsville Trough, to the north and in front of the northwestern edge of the Marion Plateau. The hole consists of a thick, $473.5 \mathrm{~m}$, sequence of Miocene-Pleistocene hemipelagic sediments overlying uppermost lower to upper Miocene shelf carbonates.

The pore-water $\mathrm{Sr}$ depth profile (Fig. 2D) is more typical of profiles normally seen from ODP sites than those described for Sites 812-814. However, profiles are complicated by the presence of elevated chloride concentrations and salinities, which, in general, show a near-linear increase with depth (Davies, McKenzie, PalmerJulson, et al., 1991). Sulfate concentrations in the pore waters decrease over the upper $\sim 200 \mathrm{~m}$ because of anoxic diagenesis but then, together with salinity, increase with depth for the remainder of the section. The Sr profile is the mirror image of that for sulfate and is probably controlled by it. The maximum concentration of $\mathrm{Sr}$ in pore waters is normally limited by celestite saturation, with the result that very high $\mathrm{Sr}$ concentrations can occur, as here, in association with sediments where dissolved $\mathrm{Sr}$ production is occurring in association with oxidation of organic matter by bacterial sulfate reduction.

${ }^{87} \mathrm{Sr} /{ }^{86} \mathrm{Sr}$ ratios in Site 815 pore waters decrease with depth from the modern seawater value to $<0.7089$ near the base of the hole. In contrast to the situation at Sites $812-814$, these ratios are lower than 


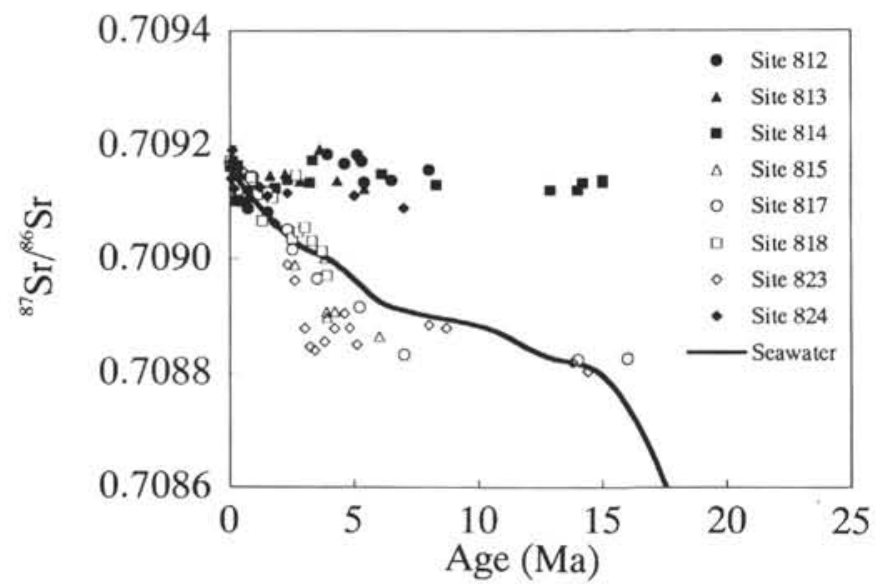

Figure $4{ }^{87} \mathrm{Sr} /{ }^{86} \mathrm{Sr}$ ratios of Leg 133 pore waters vs. age of sediments from which samples recovered, also showing the $\mathrm{Sr}$ isotope curve for seawater vs. time.

those corresponding to seawater of the age of the associated sediments (Fig. 4).

\section{Site $\mathbf{8 1 7}$}

Site 817 is situated on the northern side of the Townsville Trough, on the lower slope of the Queensland Plateau. Drilling recovered $~ 700$ $\mathrm{m}$ of carbonate platform slope sediments from late early Miocene to Pleistocene age.

Sr concentrations in the pore waters (Fig. 2E) show some similarity to those at Site 815 , although changes are less extreme. Concentrations increase to $\sim 550 \mu \mathrm{M}$ at $\sim 60 \mathrm{mbsf}$ and this upper zone is associated with decreases in aragonite from $>60 \%$ at the top of the hole to zero at $53 \mathrm{mbsf}$ (Fig. 3B). A very modest degree of sulfate reduction ( $10 \%$ of seawater values) is found at this site, which limits the increase of pore-water Sr. Below $\sim 60 \mathrm{mbsf}$, Sr concentrations decrease gradually with depth to $315 \mu \mathrm{M}$ at $270 \mathrm{mbsf}$. As at Site 815 , chloride and salinity increases occur in the deeper part of the hole (below $\sim 120 \mathrm{mbsf}$ ). ${ }^{87} \mathrm{Sr} /{ }^{86} \mathrm{Sr}$ ratios in general parallel the changes in the seawater ${ }^{87} \mathrm{Sr} /{ }^{86} \mathrm{Sr}$ ratio for the age of the sediments (Fig. 4).

\section{Site 818}

Site 818 is located on an inclined terrace on the upper slope of the Queensland Plateau. Drilling recovered a 303 m-thick sequence of periplatform sediments of early Pliocene to Pleistocene age.

Depth profiles of $\mathrm{Sr}$ concentrations and ${ }^{87} \mathrm{Sr} /{ }^{86} \mathrm{Sr}$ ratios in pore waters (Fig. 2F) are similar to Sites 815 and, particularly, 817. Sr concentrations increase with increasing depth to $\sim 70 \mathrm{mbsf}$ and are associated with the disappearance of aragonite from the sediments (Fig. 3B). Below this depth, concentrations decrease in the zone of increased chloride concentrations and salinities. There is more significant sulfate reduction than was found at Site 817 . Pore waters were saturated with respect to celestite between $\sim 50$ and 270 mbsf and celestite was found at $\sim 180$ and 270 mbsf (Davies, McKenzie, Palmer-Julson, et al., 1991).

${ }^{87} \mathrm{Sr} /{ }^{86} \mathrm{Sr}$ ratios of the pore waters decrease with increasing depth to just $<0.7090$, higher than at Sites 815 and 817 in agreement with the age of the sediments (Fig. 4).

\section{Site 823}

Site 823 is located in the central western Queensland Trough, toward the deepest part of the basin. In excess of $1 \mathrm{~km}$ of core was recovered, comprising a sequence of middle Miocene to Pleistocene hemipelagic-pelagic sediments with numerous turbidites.

Concentrations of $\mathrm{Sr}$ in pore waters (Fig. $2 \mathrm{G}$ ) are $~ 50 \%$ elevated, compared with seawater concentrations over the top $\sim 140 \mathrm{~m}$ of the hole below which concentrations increase nearly linearly with depth to almost $3,000 \mu \mathrm{M}$ at the base of the core. This $>30 \times$ enrichment over seawater values is exceptionally large and appears to result from a combination of intense bacterial sulfate reduction (pore-water sulfate reaches zero at $\sim 50 \mathrm{mbsf}$ and sulfate is near-absent $[<2 \mathrm{mM}]$ from most pore waters to a depth of $\sim 700 \mathrm{~m}$, below which it increases slightly to $5.6 \mathrm{mM}$ at $990 \mathrm{mbsf}$ ) coupled with diagenesis of aragonite and high$\mathrm{Mg}$ calcite, both of which are absent below $\sim 300$ mbsf (Fig. 3B).

${ }^{87} \mathrm{Sr} /{ }^{86} \mathrm{Sr}$ ratios of pore waters decrease with depth from seawater to $\sim 0.70885$ at $\sim 400 \mathrm{mbsf}$, below which they decrease more gradually and erratically with depth. The correspondence between ${ }^{87} \mathrm{Sr} /{ }^{86} \mathrm{Sr}$ ratios of pore waters and ratios equivalent to the sediment age (as derived from the seawater $\mathrm{Sr}$ isotope curve) is less straightforward than for Sites 815 and $816-818$ (Fig. 4). Reasonably good correspondence is found at the base of the core, where pore-water ${ }^{87} \mathrm{Sr} /{ }^{86} \mathrm{Sr}$ ratios are similar to those of mid-Miocene seawater, but similar ${ }^{87} \mathrm{Sr} /{ }^{86} \mathrm{Sr}$ ratios of pore waters are also found at $\sim 400 \mathrm{mbsf}$, in lower-upper Pliocene sediments (the ${ }^{87} \mathrm{Sr} /{ }^{86} \mathrm{Sr}$ ratio of Pliocene seawater is $>0.7090$ ).

\section{Site 824}

Site 824 is situated on the western slope of the Queensland Plateau, west of Holmes Reef. A total depth of $431 \mathrm{~m}$ was drilled until upper Oligocene-lower Miocene sediments, where basement, probably of Paleozoic age, was reached.

$\mathrm{Sr}$ concentrations in pore waters (Fig. $2 \mathrm{H}$ ) increase to $\sim 325 \mu \mathrm{M}$ at $\sim 22 \mathrm{mbsf}$, but then decrease to $\sim 250 \mu \mathrm{M}$ at depth, with slightly higher values, on average, between 22 and 150 mbsf than deeper in the hole. The increased $\mathrm{Sr}$ is associated with dissolution of aragonite; however, unlike other sites, aragonite persists to much deeper in the sediment (Fig. 3A).

${ }^{87} \mathrm{Sr} /{ }^{86} \mathrm{Sr}$ ratios of pore waters from the top $22 \mathrm{~m}$ of the hole are analytically indistinguishable from modern seawater, and then decrease abruptly to a constant value of $\sim 0.70911$ for the remainder of the section sampled. This value is equivalent to that for PliocenePleistocene seawater, although the sediments are much older.

\section{DISCUSSION}

It is possible to categorize the sites into two groups on the basis of the pore-water results described in the previous section: (1) Sites 812 through 814 and 824 ; and (2) Sites 815,817 through 818 , and 823 . The Group 1 sites are of particular interest in that the pore-water data reflect the presence of fluid flow. The Group 2 sites share the characteristic that they exhibit the possible influence of buried evaporites.

\section{Evidence for Fluid Flow}

In summary, the coupled $\mathrm{Sr}$ concentration/isotopic composition results for pore waters from Sites 812 through 814 and 824 (Figs. $2 \mathrm{~A}-2 \mathrm{C}, 2 \mathrm{H})$ may be described as a zoned system. In the upper layer, $\mathrm{Sr}$ concentrations increase and ${ }^{87} \mathrm{Sr} /{ }^{86} \mathrm{Sr}$ ratios decrease with depth as a consequence of aragonite dissolution. However, the elevated $\mathrm{Sr}$ concentrations do not persist with increasing depth and ${ }^{87} \mathrm{Sr} /{ }^{86} \mathrm{Sr}$ ratios do not decrease further, as would be expected. Despite the observation that aragonite dissolution is complete at shallow sub-bottom depths, pore-water $\mathrm{Sr}$ concentrations return to near-seawater values at depth (the lower layer). The rapid disappearance of aragonite (within the Pleistocene sections) is indicative of rapid recrystallization of aragonite to calcite, yet pore-water $\mathrm{Sr}$ concentrations are similar to seawater values in the lower layer. This observation implies that the upper layer is diffusion-reaction-dominated (aragonite dissolution and diffusive Sr transport), whereas the lower layer is advection-dominated because of fluid flow.

The $\mathrm{Sr}$ isotope data strongly support this interpretation. In the upper layer, ${ }^{87} \mathrm{Sr} /{ }^{86} \mathrm{Sr}$ ratios follow changes in seawater $\mathrm{Sr}$ isotopic composition, but in the lower layer the pore waters of near-seawater $\mathrm{Sr}$ concentrations have ${ }^{87} \mathrm{Sr} /{ }^{86} \mathrm{Sr}$ ratios that are similar to modern 
seawater values. This observation supports the suggestion that fluid flow through carbonate platforms provide a mechanism for the supply of chemical constituents to drive diagenetic reactions (Mullins et al., 1984; Simms, 1984).

Temperature measurements at Sites 812 and 814 provide additional support for fluid flow (Davies, McKenzie, Palmer-Julson, et al., 1991). At Site 812 , temperatures are near constant at $10^{\circ} \mathrm{C}$ to a depth of $225 \mathrm{mbsf}$ and then rise abruptly to $17.6^{\circ} \mathrm{C}$ at $300 \mathrm{mbsf}$, suggesting that water may be drawn through the sediments. At Site 814 , there is a sharp temperature gradient near the sediment/seawater interface that is suggestive of water flow out of the sediments. However, there are significant uncertainties associated with the interpretation of downhole temperature measurements and there are inconsistencies between the idea of vertical flow and the pore-water data which imply a lateral component to flow. For example, the ${ }^{87} \mathrm{Sr} /{ }^{86} \mathrm{Sr}$ ratio minimum at $20 \mathrm{mbsf}$ in Site 812 (Fig. 2A) is strongly suggestive of lateral flow. Similarly, if $\mathrm{Ca}$ in pore waters at Site 814 (Davies, McKenzie, Palmer-Julson, et al., 1991) is more-or-less conservative, then the flow must be very slow.

The presence of hardgrounds or lithological boundaries may provide the flow paths for such fluid flow. Considering the transect represented by Sites 812-814-813 (Figs. 2A, 2C, and 2B), one can see that at Site 812 the zone boundary corresponds to a hardground between sediment Units I and II. At Site 814, a hardground (Unit II) corresponds to the depth of the zone boundary at $\sim 70 \mathrm{mbsf}$ where the maximum in ${ }^{87} \mathrm{Sr} /{ }^{86} \mathrm{Sr}$ occurs. At Site 813 , there is no hardground and the upper $\sim 75 \mathrm{~m}$ of the sediment is characterized by pore waters with the same ${ }^{87} \mathrm{Sr} /{ }^{86} \mathrm{Sr}$ ratio, despite the strong gradient in $\mathrm{Sr}$ concentration. At this site, the upper and lower boundaries of Unit II are characterized by changing physical properties (Davies, McKenzie, Palmer-Julson, et al., 1991) and the $\mathrm{Sr}$ and ${ }^{87} \mathrm{Sr} /{ }^{86} \mathrm{Sr}$ profiles are sensitive to such changes. Tracing the outcrop of the hardgrounds on the platform using seismics is a possible next step to evaluating the pathways of fluid flow.

One method of estimating the rate of fluid flow is to calculate the water movements necessary to eradicate $\mathrm{Sr}$ concentration anomalies from aragonite dissolution of the magnitudes seen in the upper zones at these sites. Such values will be minimum rates. The $\mathrm{Sr}$ concentration gradients shown in Figure 2 for these sites range from $\sim 1$ to $8.5 \mu \mathrm{M} / \mathrm{m}$. Assuming a diffusion coefficient for $\mathrm{Sr}$ of $\sim 100 \mathrm{~cm}^{2} / \mathrm{yr}$ gives fluxes of $\sim 1$ to $8 \mu \mathrm{mol} / \mathrm{cm}^{2} / \mathrm{k}$.y. The minimum water fluxes required to eradicate pore-water $\mathrm{Sr}$ anomalies driving these fluxes are 0.05 to $0.2 \mathrm{~cm} / \mathrm{yr}$. An alternative method is through use of the Peclet number, $P_{e}$ (see Bickle and McKenzie, 1987), as

$$
P_{e}=W_{o} / h \cdot D_{f},
$$

where $h=$ the thickness of the zone of diffusive mixing, $W_{o}=$ the volume fluid flow per unit area, and $D_{f}=$ the effective diffusivity. Systems having values of $P_{e}<1$ are diffusion-dominated, and those having $P_{e}>1$ are advection-dominated. Taking Site 813 as an example, where ${ }^{87} \mathrm{Sr} /{ }^{86} \mathrm{Sr}$ data imply that mixing between the region of fluid flow and overlying seawater occurs over a subsurface depth range of $\sim 4 \mathrm{~m}$, and assuming $P_{e}=10$, gives a flow rate of $2.5 \mathrm{~cm} / \mathrm{yr}$. Both methods of estimation are crude but provide order-of-magnitude values of minimum flow rates through the carbonate platform.

\section{The Influence of Evaporites}

Increases in chloride concentrations of pore waters with depth appear to be a common feature in the Miocene/Pliocene sediments of the Queensland and Townsville troughs and have been observed at Sites $815,817,818,822$, and 823 . Evaporites are not known for these basins but evaporites have been identified in Oligocene sediments of the Capricorn Basin at $\sim 25^{\circ} \mathrm{S}$ (Ericson, 1976). Thus, it is possible that the chloride gradients reflect transport from evaporites associated with Oligocene strata at the ODP sites, which have been identified from seismic sections (Davies, McKenzie, Palmer-Julson, et al.,
1991). It has been suggested that during the post-breakup subsidence of the troughs, partially restricted shallow-marine conditions existed.

It is difficult to recognize evidence for the influence of the evaporites from pore-water $\mathrm{Sr}$ and ${ }^{87} \mathrm{Sr} /{ }^{86} \mathrm{Sr}$ data. For the majority of sites, ${ }^{87} \mathrm{Sr} /{ }^{86} \mathrm{Sr}$ ratios of pore waters appear to be controlled by diagenetic reactions within the sediment column. At Site 823, the pore-water profiles are indicative of a supply of $\mathrm{Sr}$ from below. The uppermost $\sim 150 \mathrm{~m}$ of the pore-water system appears to be in diffusive communication with the overlying water column but, at depth, ${ }^{87} \mathrm{Sr} /{ }^{86} \mathrm{Sr}$ ratios suggest upward transport of $\mathrm{Sr}$ from underlying sediments. If this feature reflects influx from evaporites, then the results may be considered in terms of two-end-member mixing, assuming that $\mathrm{Sr}$ behaves conservatively. However, this limits the end-member ${ }^{87} \mathrm{Sr} /{ }^{86} \mathrm{Sr}$ ratio only to $\sim 0.70875$ ( $15 \mathrm{Ma}$ ). Work during ODP Leg 112 (Peru margin), where high chlorinities at depth were also observed (Kastner et al., 1990; Elderfield et al., 1991), showed that profiles were consistent with the mixing of an evolved brine associated with evaporite formation with the seawater as it was transported at depth within the marginal sediments. Thus, the high-chloride end-member at a particular site may be itself a mixture of brine and seawater that is in diffusive communication with the overlying pore-water system. Therefore, the end-member Sr isotopic composition of the high-chloride end-member when translated to an isotopic age will always be younger than the age of the evaporite.

\section{SUMMARY}

The most important result obtained during this preliminary study of the Sr isotopic compositions of pore waters from Leg 133 has been the evidence that they provide for fluid flow through the Queensland Plateau. The combination of $\mathrm{Sr}$ concentrations at depth similar to seawater values and ${ }^{87} \mathrm{Sr} /{ }^{86} \mathrm{Sr}$ ratios similar to values for modern seawater associated with sediments of Miocene age provides an important first piece of definitive evidence of fluid flow through a carbonate platform, a process that often has been suggested to be important for carbonate diagenesis. The pore-water profiles showing such features (Sites 812 through 814 , and 824 ) are atypical of porewater profiles previously seen at DSDP/ODP sites and are important in that they represent the first detailed profiles of $\mathrm{Sr}$ isotopes in a transect of a carbonate platform. Profiles at other Leg 133 sites are more typical of $\mathrm{Sr}$ isotope profiles described from earlier work.

\section{ACKNOWLEDGMENTS}

We are grateful to the staff of the Ocean Drilling Program, both on and off JOIDES Resolution for their support of this work. In particular, we are pleased to acknowledge the invaluable contributions made by Peter Davies (co-chief scientist) and Amanda Palmer-Julson (shipboard staff scientist). We thank J. M. Gieskes and D. A. Hodell for their reviews of the manuscript. The work of $\mathrm{H}$. Elderfield was supported by the National Environmental Research Council (NERC). This is Cambridge Earth Sciences Series Contribution No. 2876.

\section{REFERENCES*}

Baker, P.A., Stout, P.M., Kastner, M., and H. Elderfield, 1991. Large-scale advection of seawater through oceanic crust in the central equatorial Pacific. Earth Planet. Sci. Lett., 105:522-533.

Bickle, M.J., and McKenzie, D., 1987. The transport of heat and matter by fluids during metamorphism. Contrib. Mineral. Petrol., 95:384-392.

Burke, W.H., Denison, R.E., Hetherington, E.A., Koepnick, R.B., Nelsen, H.F., and Otto, J.B., 1982. Variation of seawater ${ }^{87} \mathrm{Sr} /{ }^{86} \mathrm{Sr}$ ratio throughout Phanerozoic time. Geology, 10:516-519.

\footnotetext{
- Abbreviations for names of organizations and publication titles in ODP reference lists follow the style given in Chemical Abstracts Service Source Index (published by American Chemical Society).
} 
Davies P.J., McKenzie, J.A., Palmer-Julson, A., et al., 1991. Introduction. In Davies, P.J., McKenzie, J.A., Palmer-Julson, A., et al., 1991. Proc. ODP, Init. Repts., 133: College Station, TX (Ocean Drilling Program), 5-30.

Eberli, G.P., and Ginsburg, R.N., 1989. Cenozoic progradation of the north western Great Bahamas Bank. Soc. Econ. Paleontol. Mineral. Spec. Publ., 4:339-351.

Elderfield, H., and Gieskes, J.M., 1982. Sr isotopes in interstitial waters of Deep Sea Drilling Project cores. Nature, 300:493-497.

Elderfield, H., Kastner, M., and Martin, J.B., 1991. Compositions and sources of fluids in sediments of the Peru subduction zone. J. Geophys. Res., 95:8819-8827.

Ericson, E.K., 1976. Capricorn Basin. Econ. Geol. Austral. Papua New Guinea, Vol. 3, 7:446-450.

Kastner, M., Elderfield, H., Martin, J.B., Suess, E., Kvenvolden, K.A., and Garrison, R.E., 1990. Diagenesis and interstitial-water chemistry at the Peruvian continental margin-major constituents and strontium isotopes. In Suess, E., von Huene, R., et al., Proc. ODP, Sci. Results, 112:413-440.

Mullins, H.T., Heath, K.C., Van Buren, M., and Newton, K., 1984. Anatomy of a modern open-oceanic carbonate slope: northern Little Bahama Bank. Sedimentology, 31:141-168.
Richter, F.M., and DePaolo, D.J., 1987. Numerical models for diagenesis and the Neogene $\mathrm{Sr}$ isotopic evolution of seawater from DSDP Site 590B. Earth Planet. Sci. Lett., 83:27-38.

Sayles, F.L., Manheim, F.T., and Waterman, L.S., 1973. Interstitial water studies in small core samples. In Heezen, B.C., MacGregor, I.D., et al., Init. Repts. DSDP, 20:783-804.

Simms, M., 1984. Dolomitization by groundwater sytems in carbonate platforms. Trans. Gulf Coast Assoc. Geol. Soc., 34:411-420.

Swart, P.K., and Burns, S.J., 1990. Pore-water chemistry and diagenesis in sediments from Leg 115: Indian Ocean. In Duncan, R.A., Backman, J., Peterson, L.C., et al., Proc. ODP, Sci. Results, 115:629-645.

Swart, P.K., and Guzikowski, M., 1988. Interstitial-water chemistry and diagenesis of periplatform sediments from the Bahamas, ODP Leg 101. In Austin, J.A., Schlager, W., et al., Proc. ODP, Sci. Results, 101:363-380.

Date of initial receipt: 19 June 1992

Date of acceptance: 25 November 1992

Ms 133SR-253 